\title{
Assessment of Tight-Gas Resources in the Grand Erg/Ahnet Province of Algeria, 2019
}

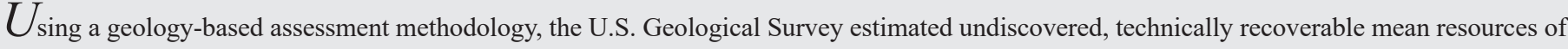 \\ 30.5 trillion cubic feet of tight gas in the Grand Erg/Ahnet Province of Algeria.
}

\section{Introduction}

The U.S. Geological Survey (USGS) completed an assessment of undiscovered, technically recoverable tight-gas resources within the Grand Erg/ Ahnet Province of Algeria (fig. 1). For this assessment, a tight-gas reservoir is defined as a gas-bearing siliciclastic reservoir that generally exhibits less than 0.1 millidarcy permeability and requires stimulation of vertical wells for production. During the early Paleozoic, much of North Africa was a northfacing passive margin with siliciclastic systems prograding northwards into the paleo-Tethys Ocean (Boote and others, 1998; Dixon and others, 2010). Regressive clastics of the Ordovician Period formed a thin sedimentary cover across much of the passive margin. Demise of the Ordovician ice cap and associated meltwaters led to the formation of large, northward-flowing channels that incised into Ordovician clastics. A major transgression in the early Silurian resulted in the deposition of organic-rich petroleum source rocks within the paleochannels; the channel deposits were overlain by regressive clastics of the late Silurian. A major transgression in the Devonian also led to the deposition of organic-rich source rocks, and these were subsequently buried by regressive clastics of the Devonian and early Carboniferous. In the middle of the Carboniferous period, Hercynian compressional deformation segmented the passive margin into a mosaic of uplifts and basins (Eschard and others, 2010). The tight-gas assessment units (AUs) defined in this study are restricted to the post-Hercynian basinal areas, as the uplifts may have lost any hydrocarbons from exhumation and erosion.

\section{Total Petroleum Systems and Assessment Units}

The USGS defined the Silurian Total Petroleum System (TPS) with the Timimoun Basin Ordovician Tight Gas AU, the Sbaa Basin Ordovician Tight Gas AU, and the Ahnet Basin Ordovician Tight Gas AU. The Mouydir Basin Ordovician Tight Gas AU was defined but not quantitatively assessed. Shales of the Silurian TPS contain as much as 10 percent total organic carbon (TOC), have hydrogen index (HI) values as much as 380 milligrams of hydrocarbon per gram of total organic carbon (mg HC/g TOC), and have shale thickness as much as 100 meters (Logan and Duddy, 1998; El Diasty and others, 2017). The boundaries of the tight-gas reservoirs were largely drawn based on the thermal generation window for gas.

The Devonian TPS includes the Timimoun Basin Devonian Tight Gas AU, the Sbaa Basin Devonian Tight Gas AU, and the Ahnet Basin Devonian Tight Gas AU. Devonian shales contain as much as 14 percent TOC, have HI values as much as $580 \mathrm{mg} \mathrm{HC} / \mathrm{g} \mathrm{TOC}$, and have shale thickness as much as 200 meters (Chaouche, 2013).

The geologic model for tight-gas systems is for hydrocarbons to have been generated from organic-rich Silurian and Devonian shales possibly as early as the lower Carboniferous (Lüning, and others, 2000). Oil would have cracked to gas in the Mesozoic (Logan and Duddy, 1998), and some of this gas was either retained within or migrated locally into Ordovician, Silurian, Devonian, and possibly early Carboniferous tight sandstones.

Key assessment input data are shown in table 1. Drainage areas, success ratios, and estimated ultimate recoveries are taken from U.S. tight-gas analogs.

\section{Undiscovered Resources Summary}

The USGS quantitatively assessed undiscovered, technically recoverable continuous tight-gas resources within six AUs in the Grand Erg/Ahnet Province (table 2) of Algeria. The estimated total mean resources are 30,474 billion cubic feet of gas (BCFG), or 30.5 trillion cubic feet of gas, with an F95-F5 range from 6,336 to 71,077 BCFG and 103 million barrels of natural gas liquids (MMBNGL) with an F95-F5 range from 18 to 262 MMBNGL.
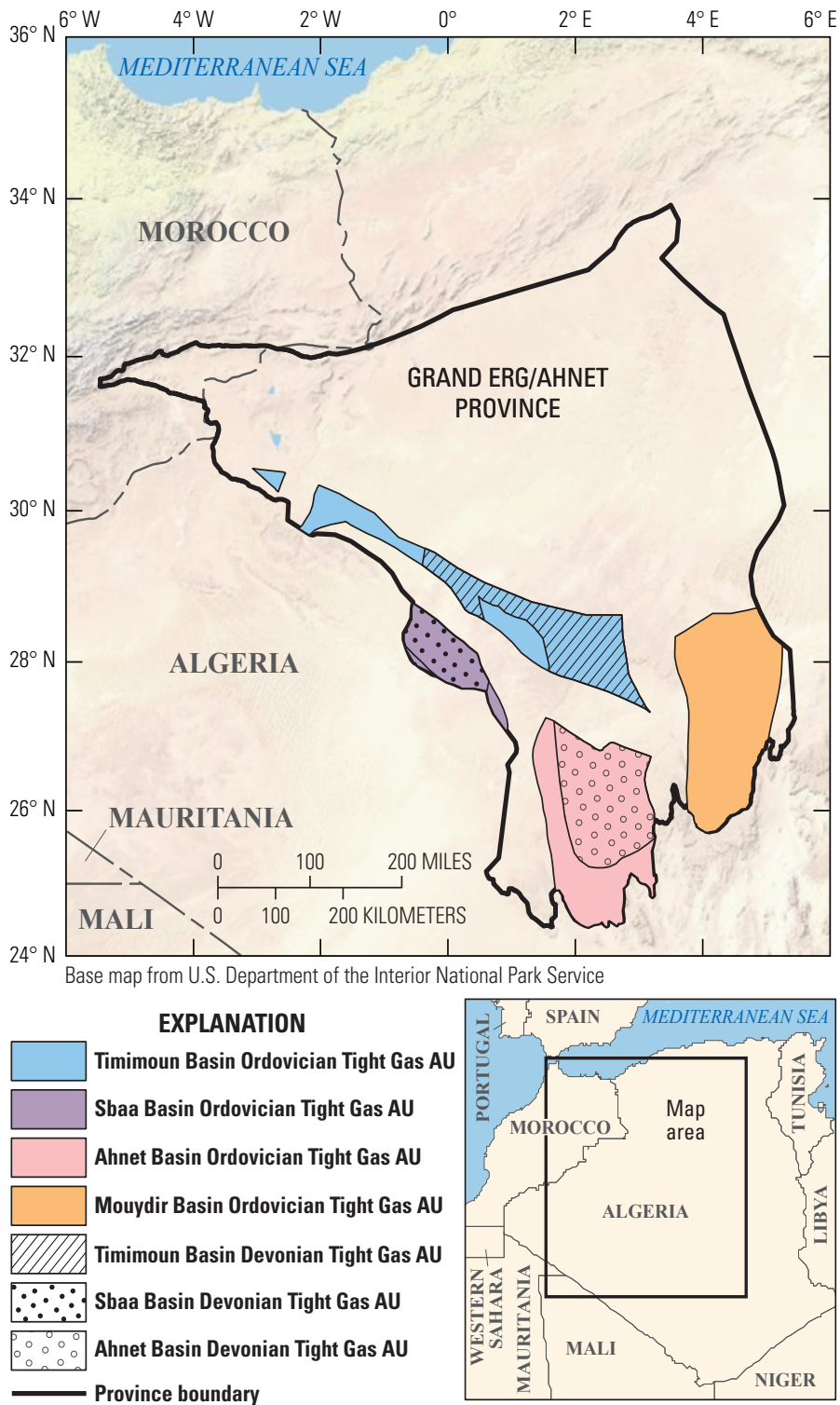

Figure 1. Location of the Grand Erg/Ahnet Province of Algeria and the six tight-gas assessment units (AUs) defined in this study. 
Table 1. Key input data for six tight-gas assessment units (AUs) in the Grand Erg/Ahnet Province of Algeria.

[Results shown are fully risked estimates. Well drainage area, success ratio, and EUR are defined partly using U.S. tight-gas analogs. The average EUR input is the minimum, median, maximum, and calculated mean. Shading indicates not applicable. \%, percent; EUR, estimated ultimate recovery; BCFG, billion cubic feet of gas]

\begin{tabular}{|c|c|c|c|c|c|c|c|c|}
\hline \multirow{2}{*}{$\begin{array}{l}\text { Assessment input data- } \\
\text { Continuous AUs }\end{array}$} & \multicolumn{4}{|c|}{ Timimoun Basin Ordovician Tight Gas AU } & \multicolumn{4}{|c|}{ Sbaa Basin Ordovician Tight Gas AU } \\
\hline & Minimum & Mode & Maximum & Calculated mean & Minimum & Mode & Maximum & Calculated mean \\
\hline Potential production area of AU (acres) & 10,000 & $3,895,500$ & $7,791,000$ & $3,898,333$ & 10,000 & $1,199,500$ & $2,399,000$ & $1,202,833$ \\
\hline Average drainage area of wells (acres) & 80 & 120 & 160 & 120 & 80 & 120 & 160 & 120 \\
\hline Untested area in AU (\%) & 100 & 100 & 100 & 100 & 100 & 100 & 100 & 100 \\
\hline Success ratio $(\%)$ & 10 & 50 & 90 & 50 & 10 & 50 & 90 & 50 \\
\hline Average EUR (BCFG) & 0.08 & 0.4 & 1.2 & 0.440 & 0.08 & 0.4 & 1.2 & 0.440 \\
\hline AU probability & 1.0 & & & & 1.0 & & & \\
\hline \multirow{2}{*}{$\begin{array}{c}\text { Assessment input data- } \\
\text { Continuous AUs }\end{array}$} & \multicolumn{4}{|c|}{ Ahnet Basin Ordovician Tight Gas AU } & \multicolumn{4}{|c|}{ Timimoun Basin Devonian Tight Gas AU } \\
\hline & Minimum & Mode & Maximum & Calculated mean & Minimum & Mode & Maximum & Calculated mean \\
\hline Potential production area of AU (acres) & 1,000 & $5,221,700$ & $10,443,400$ & $5,222,033$ & 1,000 & $2,530,500$ & $5,061,000$ & $2,530,833$ \\
\hline Average drainage area of wells (acres) & 80 & 120 & 160 & 120 & 80 & 120 & 160 & 120 \\
\hline Untested area in $\mathrm{AU}(\%)$ & 100 & 100 & 100 & 100 & 100 & 100 & 100 & 100 \\
\hline Success ratio $(\%)$ & 10 & 50 & 90 & 50 & 10 & 50 & 90 & 50 \\
\hline Average EUR (BCFG) & 0.08 & 0.4 & 1.2 & 0.440 & 0.08 & 0.4 & 1.2 & 0.440 \\
\hline AU probability & 1.0 & & & & 1.0 & & & \\
\hline \multirow{2}{*}{$\begin{array}{c}\text { Assessment input data- } \\
\text { Continuous AUs }\end{array}$} & \multicolumn{4}{|c|}{ Sbaa Basin Devonian Tight Gas AU } & \multicolumn{4}{|c|}{ Ahnet Basin Devonian Tight Gas AU } \\
\hline & Minimum & Mode & Maximum & Calculated mean & Minimum & Mode & Maximum & Calculated mean \\
\hline Potential production area of AU (acres) & 1,000 & $1,047,500$ & $2,095,000$ & $1,047,833$ & 1,000 & $2,931,300$ & $5,862,600$ & $2,931,633$ \\
\hline Average drainage area of wells (acres) & 80 & 120 & 160 & 120 & 80 & 120 & 160 & 120 \\
\hline Untested area in $\mathrm{AU}(\%)$ & 100 & 100 & 100 & 100 & 100 & 100 & 100 & 100 \\
\hline Success ratio $(\%)$ & 10 & 50 & 90 & 50 & 10 & 50 & 90 & 50 \\
\hline Average EUR (BCFG) & 0.08 & 0.4 & 1.2 & 0.440 & 0.08 & 0.4 & 1.2 & 0.440 \\
\hline AU probability & 1.0 & & & & 1.0 & & & \\
\hline
\end{tabular}

Table 2. Results for six tight-gas assessment units in the Grand Erg/Ahnet Province of Algeria.

[Results shown are fully risked estimates. F95 represents a 95-percent chance of at least the amount tabulated; other fractiles are defined similarly. Shading indicates not applicable. BCFG, billion cubic feet of gas; NGL, natural gas liquids; MMBNGL, million barrels of natural gas liquids]

\begin{tabular}{|c|c|c|c|c|c|c|c|c|c|c|}
\hline \multirow{3}{*}{$\begin{array}{l}\text { Total petroleum systems and } \\
\text { assessment units (AUs) }\end{array}$} & \multirow{3}{*}{$\begin{array}{l}\text { AU proba- } \\
\text { bility }\end{array}$} & \multirow{3}{*}{$\begin{array}{c}\text { Accum- } \\
\text { ulation types }\end{array}$} & \multicolumn{8}{|c|}{ Total undiscovered resources } \\
\hline & & & \multicolumn{4}{|c|}{ Gas (BCFG) } & \multicolumn{4}{|c|}{ NGL (MMBNGL) } \\
\hline & & & F95 & F50 & F5 & Mean & F95 & F50 & F5 & Mean \\
\hline \multicolumn{11}{|c|}{ Silurian Total Petroleum System } \\
\hline Timimoun Basin Ordovician Tight Gas AU & 1.0 & Gas & 1,463 & 5,952 & 16,519 & 7,058 & 4 & 19 & 59 & 23 \\
\hline Sbaa Basin Ordovician Tight Gas AU & 1.0 & Gas & 459 & 1,846 & 5,093 & 2,190 & 1 & 6 & 18 & 7 \\
\hline Ahnet Basin Ordovician Tight Gas AU & 1.0 & Gas & 1,955 & 7,944 & 21,930 & 9,427 & 6 & 25 & 79 & 31 \\
\hline Mouydir Basin Ordovician Tight Gas AU & & Gas & \multicolumn{8}{|c|}{ Not quantitatively assessed } \\
\hline \multicolumn{11}{|c|}{ Devonian Total Petroleum System } \\
\hline Timimoun Basin Devonian Tight Gas AU & 1.0 & Gas & 964 & 3,893 & 10,713 & 4,586 & 3 & 13 & 43 & 17 \\
\hline Sbaa Basin Devonian Tight Gas AU & 1.0 & Gas & 405 & 1,613 & 4,467 & 1,913 & 1 & 6 & 18 & 7 \\
\hline Ahnet Basin Devonian Tight Gas AU & 1.0 & Gas & 1,090 & 4,477 & 12,355 & 5,300 & 3 & 14 & 45 & 18 \\
\hline Total undiscovered continuous resources & & & 6,336 & 25,725 & 71,077 & 30,474 & 18 & 83 & 262 & 103 \\
\hline
\end{tabular}

\section{References Cited}

Boote, D.R.D., Clark-Lowes, D.D., and Traut, M.W., 1998, Palaeozoic petroleum systems of North Africa, in MacGregor, D.S., Moody, R.T.J., and Clark-Lowes, D.D., eds., Petroleum geology of North Africa: The Geological Society of London, Special Publication 132, p. 7-68.

Chaouche, A., 2013, Geological and geochemical attributes of Paleozoic source rocks and their remaining potential for unconventional resources in Erg Oriental Algerian Sahara: American Association of Petroleum Geologists, Search and Discovery Article No. 90163, 34 p., accessed June 25, 2019, at http://www.searchanddiscovery.com/abstracts/html/2013/90163ace/ abstracts/chao.htm.

Dixon, R.J., Moore, J.K.S., Bourne, M., Dunn, E., Haig, D.B., Hossack, J., Roberts, N., Parsons, T., and Simmons, C.J., 2010, Integrated petroleum systems and play fairway analysis in a complex Palaeozoic basin - Ghadames-Illizi Basin, North Africa, in Vining, B.A., and Pickering, S.C., eds., Petroleum geology—From mature basins to new frontiers - Proceedings of the 7th Petroleum Geology Conference, London, England, March 30-April 2, 2009: The Geological Society of London, Petroleum Geology Conference Series, v. 7, p. 735-760.
El Diasty, W.S., El Beialy, S.Y., Anwari, T.A., and Batten, D.J., 2017, Hydrocarbon source potential of the Tanezzuft Formation, Murzuq Basin, south-west Libya-An organic geochemical approach: Journal of African Earth Sciences, v. 130, no. 1, p. $102-109$.

Eschard, R., Braik, F., Bekkouche, D., Ben Rahuma, M., Desaubliaux, G., Deschamps, R., and Proust, J.N., 2010, Paleohighs - Their influence on the North African Paleozoic petroleum systems, in Vining, B.A., and Pickering, S.C., eds., Petroleum geology-From mature basins to new frontiers-Proceedings of the 7th Petroleum Geology Conference, London, England, March 30-April 2, 2009: The Geological Society of London, Petroleum Geology Conference Series, v. 7, p. 707-724.

Logan, P., and Duddy, I., 1998, An investigation of the thermal history of the Ahnet and Reggane Basins, central Algeria, and the consequences for hydrocarbon generation and accumulation, in MacGregor, D.S., Muddy, R.T.J., and Clark-Lowes, D.D., eds., Petroleum geology of North Africa: The Geological Society of London, Special Publication 132, p. 131-155.

Lüning, S., Craig, J., Loydell, D.K., Štorch, P., and Fitches, B., 2000, Lower Silurian 'hot shales' in North Africa and Arabia-Regional distribution and depositional model: Earth-Science Reviews, v. 49, no. 1-4, p. 121-200.

\section{For More Information}

Assessment results are also available at the USGS Energy Resources Program website at https://energy.usgs.gov.

\section{Grand Erg/Ahnet Province Assessment Team}

Michael E. Brownfield, Christopher J. Schenk, Tracey J. Mercier, Marilyn E. Tennyson, Cheryl A. Woodall, Thomas M. Finn, Phuong A. Le, Janet K. Pitman, Ronald M. Drake II, Stephanie B. Gaswirth, and Heidi M. Leathers-Miller 